\title{
THE PUNCH PLANTER, SPECIFICATION AND EVALUATION
}

\author{
Ismail, Z. E*
}

\section{$\underline{\text { ABSTRACT }}$}

A prototype punch planter for no-tillage corn was developed to provide different seed spacing. Plant distribution per feddan was adjusted by changing planter punch connecting rod. Seed spacing of 136, 163, and $194 \mathrm{~mm}$ were obtained by changing the reciprocating crank radius with different punch tube lengths, represented 550, 450, and $350 \mathrm{~mm}$ respectively. The machine is constructed, manufactured and tested in experimental lab. at agricultural engineering Mansoura University. The effect of an oscillating tube mechanism on the seed's distribution by calculating seed's spacing, miss index, multiples index, and quality of feed index, precisions in spacing and the amount of seed rate was recognized. The data were statistically analyzed to determine the effect of the oscillating tube radii and the traveling speed of punch planter under three different of the connecting rod length "punch reciprocated radius" (35, 55 and $100 \mathrm{~mm})$ on performance. The smallest punching tube length $(350 \mathrm{~mm})$ had the best results at $0.39 \mathrm{~m} / \mathrm{s}$, with a quality of feed index of $95.1 \%$ and precision of $3.92 \%$. The multiples index and miss index, not always significant, as complementary of quality of feed index, were the lowest at $0.39 \mathrm{~m} / \mathrm{s}$.

\section{INTRODUCTION}

The idea to put the seed in soil by punch's holes in the soil and
drops seeds in them is identified. This idea is designed for no-
tillage systems were a substantial plant residue is left in the field. The punch planter for corn was designed, prototyped, and evaluated for no-tillage conditions using a commercial seed metering device. Referring to a planter using a finger pickup metering unit, the data from the Prairie Agricultural PAMI (1984a), collected on a greased belt, show a quality of feed index of $97 \%$ to $88 \%$ for $2.22 \mathrm{~m} / \mathrm{s}$ and $96 \%$ to $87 \%$ for $3.06 \mathrm{~m} / \mathrm{s}$ travel speed.

*Prof. Dr of power technology and farm machinery, Agric. Eng. Dept., Mansoura University. ismailze221@ mans.edu.eg 
For a machine using an airflow seed meter PAMI (1984b) reports a quality of feed index of $97 \%$ to $91 \%$ for $2.22 \mathrm{~m} / \mathrm{s}$ and $97 \%$ to $88 \%$ for $3.61 \mathrm{~m} / \mathrm{s}$ travel speed. That idea is based on a set of two plates with opposite spiral slots and a third plate with radial slots in between those two. With an external effort, the punches attached to the sliding plates will expand or contract. The prototype was built and required also a personalized vacuum seed meter. Furthermore, it was supplied with a punch wheel that can adjust its diameter, so the tips will change the distance, producing seed spacing that may vary from 0.16 to $0.21 \mathrm{~m}$. The multiples index (more than one seed in one space) increased up to 5.0\% when compared to laboratory results. Emergence may have been affected by environmental conditions, but the precision during field tests was better than in the laboratory tests. Another tray was carried out by Molin et al. (2002). Ismail and El-hanify (2009) investigated a new mechanism of the punch planter system based on small smart machines. The idea of this system is put the seed in soil by punch's holes in the soil and drops seeds. The data were statistically analyzed to determine the effect of the oscillating tube radii and the traveling speed of the punch planter under two different of the connecting rod length $(150$, and $180 \mathrm{~mm})$. The optimum parameters were found at punch planter speed of $0.6 \mathrm{~m} / \mathrm{s}$ and oscillating tube radius of $12 \mathrm{~cm}$ and connecting tube rod of $180 \mathrm{~mm}$.

A punch planter may offer better seeding performance than conventional planters for no-tillage conditions because it moves a minimum amount of soil and residue and offers precision in seed spacing. Minimal research has been completed to overcome some limitations that these machine concept offers, specifically mechanisms to change population rate. Plant population stands have been widely studied. Local recommendations for corn populations are available. Schueller (1992) reported that seed companies have tried to match their hybrids to localized conditions. Research in this area tends to continue because of the increased importance given to cite exact management. The adoption of a specific plant population for each environmental condition has been studied and proposed as a management solution for yield improvement (West et al.1998). Corn population rates have increased by more than $20 \%$ since 1980 in many areas of the Egypt. 
Even in areas where the soil residual is not a limitation, farmers still have problems dealing with residue in no-tillage conditions, indicating that research for no-tillage planting needs to be continued. The punch planter is an alternative concept for no-tillage with precision as it rolls over the residue. This research focused on some of the questions related to punching planter performance with changes in seed distribution and oscillating tube of the punch mechanism.

\section{MATERIALS AND METHODS}

\section{1- The punch planter design}

The specifications of the punch planter prototype are the driver wheel diameter of $600 \mathrm{~mm}$, thickness of $7 \mathrm{~mm}$ and $50 \mathrm{~mm}$ wide. It equipped with special inversely triangle form made from iron to reduce the slippage and to increase the rolling efficiency (Fig. 1). It also is having the oscillating tube mechanism that consists of a four-bar mechanism. It was design to realize the vertical straight-line displacement. The displacement stroke was regulated with the crank length. The motion is translated to the oscillating tube mechanism from the drive wheel by the transmission system. The metering device was connected to the frame of a planter. Through chain and sprockets a drive wheel was providing rotation to the horizontal seed disc. Seed metering system, is seeding plate types. The seed plate is edge-drop plate; it has cells and rotates at the bottom of a seed hopper. The kernels fall into the cells on the edge and dropped inside the oscillating tube mechanism. The seed holding number is regulated by changing the number of holes on the metering disc or by changing the rotational speed of metering disc.

\section{2- The punch planter calibration}

The punch planter operated by human power (Fig. 1) was designed for seeding in fields with zero tillage. The process could be divided into three steps: 1) drilling 2) seeding and 3) hole closing. During the drilling step, the puncher penetrated into the soil by the action of the rotating counterweight (felly wheel) on the crank shafts for the four bears mechanism that pushing the free part of the punch system. Consequently, the planter provided impact force in this step. Seeding was done by harmonizing the action of the roller mechanism motion and puncher transmission motion when the seeds from the hopper were dropped into the holes through the metering device. 


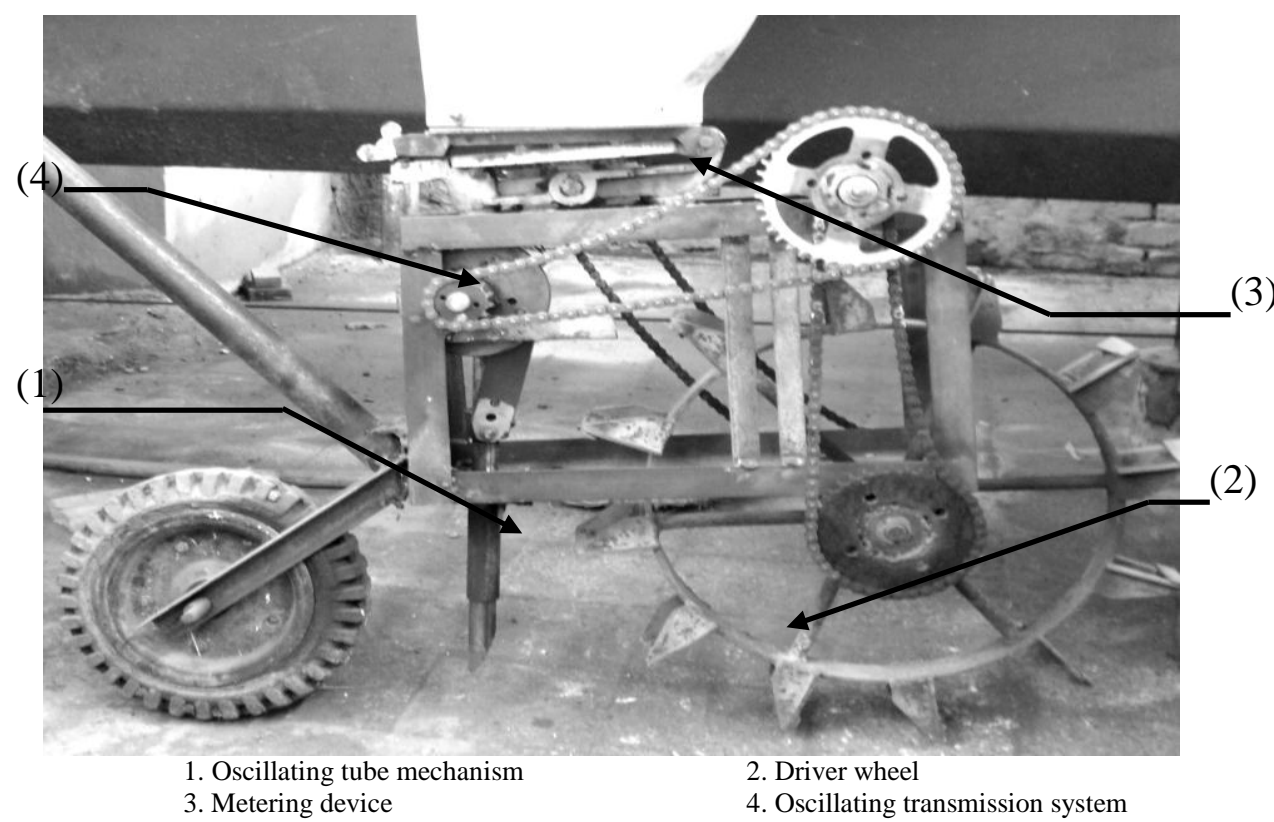

Fig. 1: The investigated punch planter (Ismail, 2009)

The prototype was 550 wide, $900 \mathrm{~mm}$ long and $600 \mathrm{~mm}$ high. It was a one row planter with the variable row seed spacing of 100 to $250 \mathrm{~mm}$, varied by adjusting the sleeve arrangement of transmission motion. The puncher was increased in length from $50 \mathrm{~mm}$ to $80 \mathrm{~mm}$, to enable it to penetrate the un-burnt residual and reach the soil. The hole-to hole spacing could be adjusted from 136, 163, and $194 \mathrm{~mm}$ by changing the reciprocating crank radius with different punch tube lengths, represented 550,450 , and $350 \mathrm{~mm}$ respectively. The metering device was regulated for two to three corn seed for each hole with $12 \mathrm{~mm}$ diameter and 5 - 7 $\mathrm{mm}$ depth regarding to punch speed-(5 holes per meter). The capacity of the seed tank was 0.03 Liter for each device.

\section{The field experimental}

The experiment was carried out at a special field in Monsoura, Egypt. The experimental site was previously under alfalfa cultivation and harvested by a mower harvester model. The soil moisture content was 17 $\%$ (w.b.) two conditions of straw (residual) managements were applied. Firstly, the straw is remanded on the field surface and secondly, straw as left by the mower harvester. The corn grain was tested an evaluation by 
the investigated punch planter. The main specification of corn (Trabel Hoogen 324 variety) tabulated in tables (1) and (2).

Table 1: Some of physical properties of corn seeds

\begin{tabular}{|c|c|c|c|c|c|c|c|c|c|}
\hline $\begin{array}{c}\mathrm{L}, \\
\mathrm{mm}\end{array}$ & $\begin{array}{c}\mathrm{W}, \\
\mathrm{mm}\end{array}$ & $\begin{array}{c}\mathrm{T}, \\
\mathrm{mm}\end{array}$ & $\begin{array}{c}\mathrm{M}, \\
\mathrm{g}\end{array}$ & $\begin{array}{c}\mathrm{d}_{\mathrm{g}}, \\
\mathrm{mm}\end{array}$ & $\begin{array}{c}\mathrm{d}_{\mathrm{a}}, \\
\mathrm{mm}\end{array}$ & $\begin{array}{c}\mathrm{a}_{\mathrm{fs}}, \\
\mathrm{mm}\end{array}$ & $\begin{array}{c}\mathrm{a}_{\mathrm{ts}}, \\
\mathrm{mm}\end{array}$ & $\begin{array}{c}\mathrm{S}_{\mathrm{p}}, \\
\%\end{array}$ & $\begin{array}{c}\mathrm{MC}, \\
\%\end{array}$ \\
\hline 10.54 & 7.26 & 4.57 & 0.268 & 7.25 & 116.57 & 164.81 & 204.11 & 67.71 & 12.78 \\
\hline 10.82 & 7.64 & 4.85 & 0.364 & 7.59 & 130.87 & 180.82 & 219.08 & 70.27 & 14.30 \\
\hline 11.16 & 7.69 & 5.19 & $\mathrm{o} .372$ & 7.93 & 148.20 & 197.25 & 238.00 & 70.77 & 17.40 \\
\hline
\end{tabular}

Where:- L: length, W: width, $\mathrm{T}$ : thickness, M: mass, $\mathrm{d}_{\mathrm{g}}$ : geometric diameters, $\mathrm{d}_{\mathrm{a}}$ : arithmetic diameters., $\mathrm{a}_{\mathrm{fs}}$ : area of flat surface, $\mathrm{a}_{\mathrm{ts}}$ : area of transverse surface, $\mathrm{s}_{\mathrm{p}}$ : spherically, and MC: moisture content dry basis

Table 2 : The mechanical properties of corn seeds

\begin{tabular}{|c|c|c|c|c|}
\hline $\begin{array}{c}\text { Specific } \\
\text { mass, } \mathrm{g}\end{array}$ & $\begin{array}{c}\text { Angle of } \\
\text { repose, degree }\end{array}$ & $\begin{array}{c}\text { Friction angle, } \\
\text { degree* }^{*}\end{array}$ & $\begin{array}{c}\text { Rigidity } \\
\text { force, } \mathrm{N}\end{array}$ & $\begin{array}{c}\text { Terminal } \\
\text { velocity, } \mathrm{m} / \mathrm{s}\end{array}$ \\
\hline $7.0 \pm 0.35$ & $22.91 \pm 2.18$ & $23.6 \pm 1.16$ & $80.82 \pm .82$ & $8.18 \pm 0.98$ \\
\hline
\end{tabular}

* Friction angle with sheet metal surface.

\section{The variables and majoring parameters}

The work was based on a seed spacing of 136, 163, and $194 \mathrm{~mm}$ were tested, along with punch speeds of $0.39 ; 0.49 ; 0.59$ and $0.69 \mathrm{~m} / \mathrm{s}$, both in the laboratory and in the field. The evaluation was based on spacing between seeds or plants. The transmitted system's ratio between the revolution numbers of metering disc and the oscillating of punching tube is regulated to keep the synchronize between seed space and seed dropping from metering device. The tests were replicated three times for each treatment of the punch planter. The data were statistically analyzed to determine the effect of the oscillating tube radii and the punching speed of the punch planter under three different of the punching tube length $(350,450$ and $550 \mathrm{~mm})$ on performance indices, namely mean seed spacing, miss index, multiples index, and quality of feed index, precisions in spacing and the amount of seed rate.

Seed miss index $\left(S_{m}, \%\right)$

The seed misses index could be considered as the first indicator for the seed disposing performance. It was estimated for each treatment by counting the number of hole/cells that have no seeds and counting the 
number of the used holes/cells in each treatment. Then the percentage of missed index $\left(\mathrm{S}_{\mathrm{m}}, \%\right)$ can be calculated as follows (Ismail, 2009)

$$
S m, \%=\frac{B_{n}}{M} * 100
$$

The seeds multiples index $\left(\mathbf{S}_{\mathrm{mu}} \%\right)$ The seed double ratio could be considered as the second indicator for the seed disposing performance. It was estimated for each treatment by counting the number of holes that have more than one seed and counting the number of the total holes in each treatment. Then the percentage of seed's multiples index can be calculated as follows:

$$
S_{m u}, \%=\frac{A_{n}}{M} * 100
$$

Where:

$\mathrm{B}_{\mathrm{n}}=$ The number of holes that have no seeds.

$M=$ The total number of the used holes/sells.

$A_{n}=$ The number of holes that have more than one seeds.

\section{The quality of feed index (UH, \%)}

The uniformity of the seed in the row could be considered as the third indicator for the seed disposing performance. It was estimated by calculating the seed miss index and the seed multiples index. Then the percentage of the quality of feed index in the row can be calculated as follows:

$$
U H, \%=100-(S m, \%+S m u, \%)
$$

\section{The seed precision index (SP, \%)}

Precision $(\mathrm{Sp}, \%)$ is the coefficient of variation of the spacing between the nearest plants in a row that are classified as singles after omitting the outliers consisting of misses and multiples. The Duncan's test was used to analyses the obtained data under different variables.

\section{RESULTS AND DISCUSSION}

\section{Factors influence punch planter performance:}

The first approach to the statistical analysis of the laboratory data was to fit a second-order response surface for each variable tested against punch speed and punching tube length. However, since most analyses had 
significant, a response surface analysis was suitable. Seed distribution parameters (miss index, multiples index, quality of feed index, and precision) of the laboratory tests are presented in table (3), as well as the probabilities of "F test" and least significant differences (LSD) at 5\% probability. Probabilities of "F test" were significant for all the variables tested.

The smallest punching tube length $(350 \mathrm{~mm})$ had the best results at punch speed of $0.39 \mathrm{~m} / \mathrm{s}$, with a quality of feed index of $95.1 \%$ and precision of $3.92 \%$. The multiples index and miss index, not always significant, as complementary of quality of feed index, were the lowest at punch speed of $0.39 \mathrm{~m} / \mathrm{s}$. In work of Molin et al. (2002), using only the small wheel and before performing some major changes in the prototype, observed similar results. However, no effect of punch speed between $0.39 \mathrm{~m} / \mathrm{s}$ and $0.59 \mathrm{~m} / \mathrm{s}$ was observed. Almost the same response occurred with the largest reciprocated radius $(100 \mathrm{~mm})$. Precision was even better $(2.1 \%)$, but the multiples index was high at all three punch speeds. Also, a high miss index was observed at punch speed of $0.59 \mathrm{~m} / \mathrm{s}$, resulting in the lowest quality of feed index of all treatments. For the intermediate size of punching tube length $(450 \mathrm{~mm})$ the results were opposite, with the poorest results at punch speed of $0.59 \mathrm{~m} / \mathrm{s}$. This behavior may be related to the dropping position angle of the seed meter. The results show that the synchronization between seed meter and punch wheels is a major factor that needs special attention for accurate results. At punch speed of $0.69 \mathrm{~m} / \mathrm{s}$ the data not significant, so there are neglected in table (3).

\section{The synchronization between seed metering device and punch system:}

\section{Quality of feed index}

Some high values for quality of feed index were observed. They were not directly related to punch speed and punch reciprocated radius, suggesting that synchronization between the seed meter device and punch systems has to be improved. The length of the punches, with punch reciprocated radius up to $55 \mathrm{~mm}$, did not represent a technical limitation for the range of punch speeds between 0.39 and $0.69 \mathrm{~m} / \mathrm{s}$. The Effect of the interaction between punching speed and reciprocating radius of the punch planter on the seed feed index are illustrated in Table 4. 
Table (3): The factors influence punch planter performance at tube length $350 \mathrm{~mm}$.

\begin{tabular}{|c|c|c|c|c|c|}
\hline $\begin{array}{c}\text { Punch speed } \\
\text { m/s }\end{array}$ & $\begin{array}{c}\text { Seed } \\
\text { space }\end{array}$ & $\begin{array}{c}\text { Miss } \\
\text { index, \% }\end{array}$ & $\begin{array}{c}\text { Feed, } \\
\text { Index }\end{array}$ & $\begin{array}{c}\text { Multiples } \\
\text { index, \% }\end{array}$ & $\begin{array}{c}\text { Precision } \\
\text { index, \% }\end{array}$ \\
\hline \multirow{5}{*}{0.39} & 136 & 6.5 & 86.1 & 7.4 & 9.00 \\
\cline { 2 - 6 } & 163 & 4.1 & 95.1 & 0.8 & 3.92 \\
\cline { 2 - 6 } & 194 & 4.9 & 91.8 & 3.3 & 6.90 \\
\cline { 2 - 6 } & SD & 1.22 & 4.55 & 3.33 & 2.51 \\
\cline { 2 - 6 } & $\mathrm{X}^{\prime}$ & 5.17 & 91 & 3.83 & 6.63 \\
\cline { 2 - 6 } & $\mathrm{C} . \mathrm{V}$ & 23.65 & 5.00 & 86.93 & 37.85 \\
\hline \multirow{5}{*}{0.49} & 136 & 1.6 & 98.4 & 0.0 & 4.4 \\
\cline { 2 - 6 } & 163 & 6.5 & 88.6 & 4.9 & 7.9 \\
\cline { 2 - 6 } & 194 & 2.5 & 95.9 & 1.6 & 5.6 \\
\cline { 2 - 6 } & $\mathrm{SD}$ & 2.61 & 5.09 & 2.33 & 1.78 \\
\cline { 2 - 6 } & $\mathrm{X}^{\prime}$ & 3.53 & 94.3 & 3.25 & 5.97 \\
\cline { 2 - 6 } & $\mathrm{C} . \mathrm{V}$ & 73.82 & 5.40 & 71.80 & 29.81 \\
\hline & 136 & 8.6 & 88.6 & 2.9 & 2.9 \\
\cline { 2 - 6 } & 163 & 6.9 & 92.2 & 0.8 & 2.1 \\
\cline { 2 - 6 } & 194 & 9.8 & 83.3 & 6.9 & 4.9 \\
\cline { 2 - 6 } & $\mathrm{SD}$ & 1.46 & 4.48 & 3.10 & 1.44 \\
\cline { 2 - 6 } & $\mathrm{X}^{\prime}$ & 8.43 & 88.03 & 3.53 & 3.30 \\
\cline { 2 - 6 } & $\mathrm{C} . \mathrm{V}$ & 17.28 & 5.09 & 87.71 & 43.70 \\
\hline \multirow{5}{*}{0.59} & & & & \\
\hline
\end{tabular}

It was found that the punching speed $(0.39,0.49,0.59$ and $0.69 \mathrm{~m} / \mathrm{s})$ affected the seed feed index at $1 \%(\mathrm{P}<0.01)$ significance. The differences between the seed feed index mean of the punching speed levels $\left(\chi^{-1}\right)$ were significant according to the results of Duncan's test (Table 4). The punching speed is in inversely proportion and while the punching speed was increasing the value of the seed index also decreased. As shown in Table (4), the highest seed feed index was with $\mathrm{R}_{1}(86.08 \%)$ at punch speed of $0.39 \mathrm{~m} / \mathrm{s}$, whereas the lowest seed feed index was $(46.21 \%)$ at punch speed of $0.69 \mathrm{~m} / \mathrm{s}$ with reciprocated radius $\left(\mathrm{R}_{3}\right)$ of $100 \mathrm{~mm}$. When the seed feed index was $86.73 \%, 79.77 \%$ and $74.56 \%$ for $R_{1}, R_{2}$ and $R_{3}$ punch reciprocated mechanism at $0.39 \mathrm{~m} / \mathrm{s}$ punch speed, the seed feed index reached $71.04 \%, 61.07 \%$ and $46.21 \%$, respectively, in a punching speed of $0.59 \mathrm{~m} / \mathrm{s}$. The changing punching speed had a greater effect on the feed index of $R_{3}$ punch reciprocated mechanism on the other one. 
Table 4: The effect of punch speed on the feed index

\begin{tabular}{|c|c|c|c|c|}
\hline \multirow{2}{*}{$\begin{array}{c}\text { Punch speed, } \\
\mathrm{Ms}^{-1}\end{array}$} & \multicolumn{4}{|c|}{ Seed feed index; \% } \\
\cline { 2 - 5 }$(35 \mathrm{~mm})$ & $\begin{array}{c}\mathrm{R}_{2} \\
(55 \mathrm{~mm})\end{array}$ & $\begin{array}{c}\mathrm{R}_{3} \\
(100 \mathrm{~mm})\end{array}$ & $\chi^{-1}$ \\
\hline 0.39 & 86.73 & 79.77 & $74.56^{*}$ & 80.35 \\
\hline 0,49 & 76.52 & 60.36 & $60.34^{*}$ & 65.74 \\
\hline 0.59 & 56.28 & 46.87 & $35.98^{*}$ & 46.38 \\
\hline 0.69 & 71.04 & 61.07 & $46.21^{*}$ & 59.44 \\
\hline$\chi^{-2}$ & 72.65 & 62.08 & $54.27^{*}$ & 62.98 \\
\hline
\end{tabular}

* Differences at $1 \%$ level

Best results were observed for the smaller punch reciprocated radius, but good results were observed for both low and high punch speeds and the medium punch reciprocated radius. This shows that the length of the punches in the tested range did not affect the performance of the prototype. The results also indicate the necessity of improved synchronization between the seed meter and punch reciprocated radius.

\section{Miss index}

Each punch reciprocated radius showed a relatively uniform miss index among punch speeds at punch tube length of $450 \mathrm{~mm}$ (Fig. 2). The target misses index was $5.0 \%$ on each reciprocated radius, but the adjusting system was very limited in its miss precision. Only in the punch reciprocated radius of $35 \mathrm{~mm}$ have a significant change in miss index between punch speed of $0.39 \mathrm{~m} / \mathrm{s}$ and the other punch speeds. The intermediate punch reciprocated radius $(55 \mathrm{~mm})$ produced significant differences in miss index at the four punch speeds in any of the three punch reciprocated radius. For the largest punch reciprocated radius $(\mathrm{PRR}=100 \mathrm{~mm})$, the seed misses index produced a significant value's difference between punch speed of $0.39 \mathrm{~m} / \mathrm{s}$ and $0.69 \mathrm{~m} / \mathrm{s}$. From these observations, the punch speed was not considered a major concern. As mentioned, each punch reciprocated radius had a different setup for seed miss control. This resulted in some average differences in seed miss among the three punch reciprocated radius. 


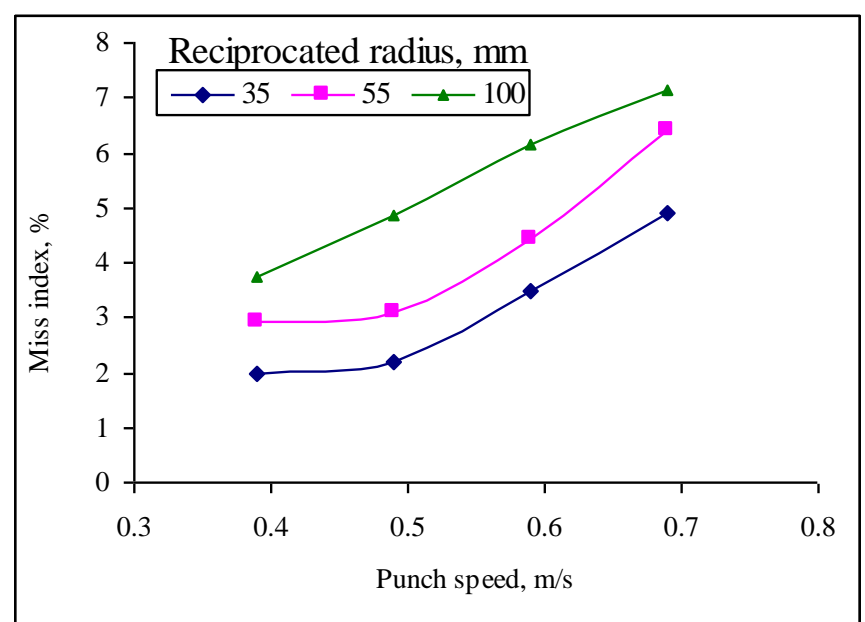

Fig. (2): The corn seed misses index of the punch planter

A Multiple regression type of data analysis was applied to relate the change in seed miss index under the effect of punch speed (PS) as interaction with the punch reciprocated radius (RR). The obtained regression equations were in the form of:

$$
\begin{array}{r}
\mathrm{S}_{\mathrm{m}}, \%=3.267+23.583(\mathrm{PS})^{2}-15.471(\mathrm{PS})+0.0254(\mathrm{RR})+0.017(\mathrm{PS}) \\
\text { ( (RR) } \mathrm{R}^{2}=0.969
\end{array}
$$

The above equation indicated that increasing the punch speed by one unit increasing the seed miss index about 1.30 times at constant punch reciprocated radius.

\section{Quality of multiple indexes $\left(\mathrm{S}_{\mathrm{mu}} \%\right)$}

The effect of punch reciprocated radius, punch speed and punch tube length on the seed multiple indexes are illustrated in Fig (3-a). All measurements of operation parameters were affected by inter-row spaces $(\mathrm{S} 1=550 \mathrm{~mm} ; \mathrm{S} 2=450 \mathrm{~mm}$ and $\mathrm{S} 3=350 \mathrm{~mm}$ ). The data analysis shows that punch tube length (PL, mm), punch speed, $(\mathrm{m} / \mathrm{s})$ and punch reciprocated radius (RR) significance affected the multiple index at $1 \%$ $(\mathrm{P}<0.01)$. The differences between the seed multiple index means of punch tube length, punch speed and punch reciprocated radius $\left(\chi^{-1}\right)$ were significant according to the results of Duncan's test $\left(\chi^{-1}=9.57,6.5\right.$ and 3.1 at "PL" of 550, 450 and $350 \mathrm{~mm}$ respectively, 8.90, 11.03, 14.43 and 18.73 "PS" of $0.39,0.49,0.59$ and $0.69 \mathrm{~m} / \mathrm{s}$ respectively and $13.90,13.10$ and 11.51 "IRS" respectively). The relation in Figs (3-b and 3-c) indicated that the seed multiple index increased by increasing each of 
seed inter row space and reciprocating radios. But the decreasing rate of multiple index as affected punch speed is more than the punch tube length effect and the vice versa at the increase the punch speed.A multiple regression type of data analysis was applied to relate the change in seed multiple indexes ( $\left.\mathrm{S}_{\mathrm{mu}} \%\right)$ under the effect of punch speed (PS) as interaction with the punch reciprocated radius (RR), the punch tube length (PL) and the seed inter row spacing (IRS). The obtained regression equations were in the form of:

$$
\begin{aligned}
& \mathrm{S}_{\mathrm{mu}} \%=-18.8291+0.2693(\mathrm{RR})-0.00134(\mathrm{RR})^{2}+0.0476(\mathrm{PL}) *(\mathrm{RR})-0.0002(\mathrm{PL}) \\
& \mathrm{R}^{2}=0.95095 \text { at effect of }(\mathrm{RR}) \\
& \mathrm{S}_{\mathrm{mu}} \%=-111.236+1.195(\text { IRS })+60.495(\mathrm{PS})-0.003(\text { IRS })^{2}-0.167(\mathrm{PS}) *(\mathrm{IRS}) \\
& \mathrm{S}_{\mathrm{mu}} \%=131.0672-0.4823(\mathrm{PL})-0.0622(\mathrm{IRS})+0.0005(\mathrm{PL})^{2} \\
& \mathrm{R}^{2}=0.84692 \text { at effect of (IRS) } \\
& +0.00005(\mathrm{PL}) *(\mathrm{IRS}) \\
& \mathrm{R}^{2}=0.99614 \text { at effect of (PL) }
\end{aligned}
$$

The first equation indicated that increasing the punch reciprocated radius (RR) by one unit increasing the multiple index about 1.29 times at constant punch tube length. But, the medium equation pointed out that increasing the punch speed one unit the multiple index increased about 1.37 at fixed the inter row spacing, while the last equation indicated the same trend.

\section{Quality of precision index (SP,\%)}

Data in Fig (4) demonstrate the effect of punch tube length, punch speed, and punch reciprocated radius on the amount of seed precision in percentages. Increasing the punching speed with constant inter-row seed spaces decrease the quantities of dropped seeds. Consequently, the percentage of seed precision is decreased until average punching speed of $0.49 \mathrm{~m} / \mathrm{s}$ after than the precision index increased. The same trend is found at affecting the peripheral punch speed. The data analysis shows that the punch tube length, punch speed, and reciprocated radius affected the precision index at $1 \%(\mathrm{P}<0.01)$ significance. The differences between the seed multiple index means of punch tube length, punch speed, and punch reciprocated radius $\left(\chi^{-1}\right)$ were significant according to the results of Duncan's test $\left(\chi^{-1}=11.73,10.87\right.$ and 10.07 at "PL" of 550, 450 and $350 \mathrm{~mm}$ respectively, 31.2, 22.9, 18.93 and 27.53 "PS" of 0.39, $0.49,0.59$ and $0.69 \mathrm{~m} / \mathrm{s}$ respectively and $13.90,13.10$ and 11.51 "IRS" respectively). 
FARM MACHINERY AND POWER

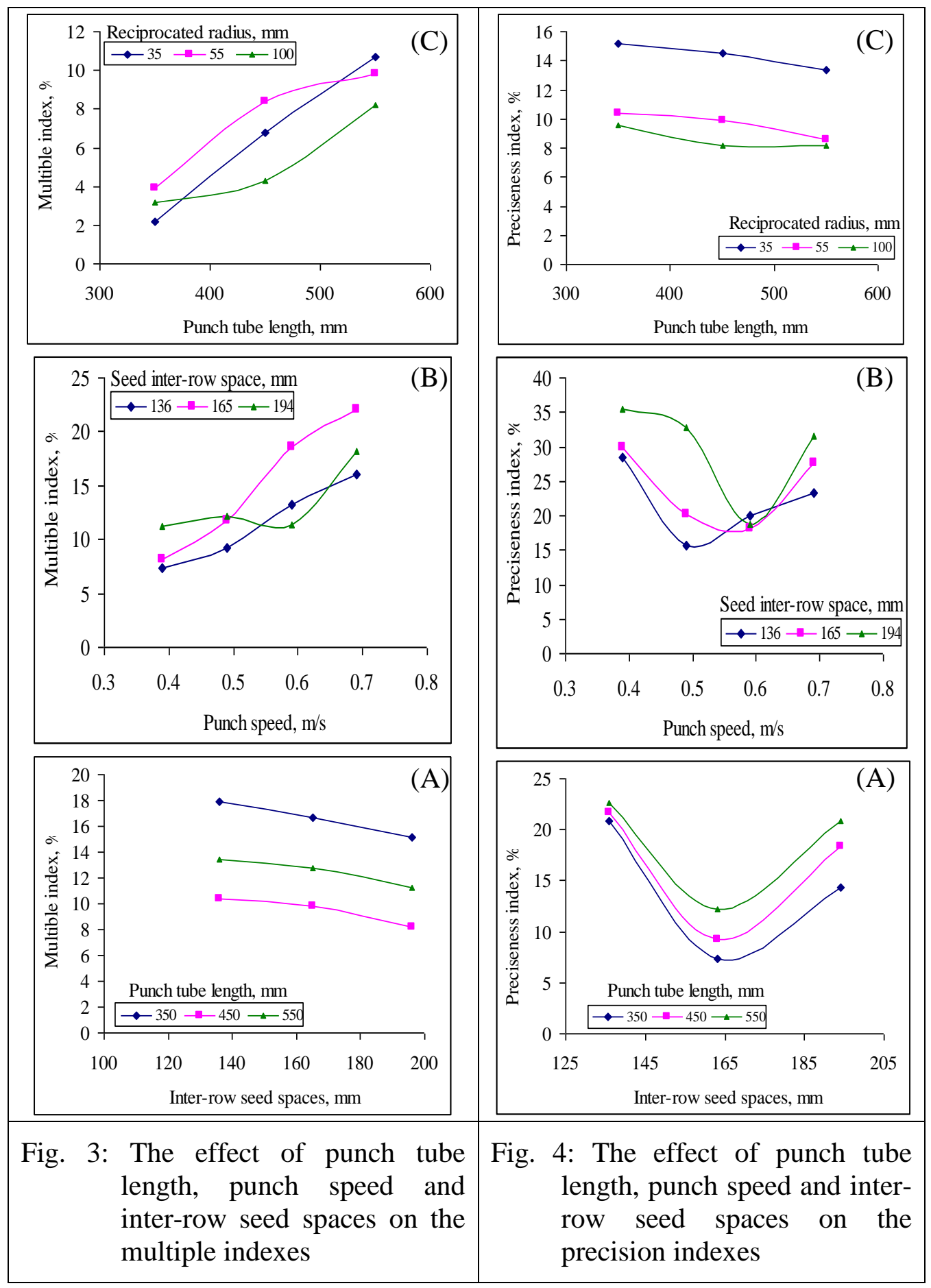


A Multiple regression type of data analysis was applied to relate the change in seed precision index (SP,\%) under the effect of punch speed (PS) as interaction with the punch reciprocated radius (RR), the punch tube length (PL) and the seed inter row spacing (IRS). The obtained regression equations were in the form of:

SP, \% $=33.7157-0.5495(\mathrm{RR})+0.00331(\mathrm{RR})^{2}-0.0104(\mathrm{PL})^{*}(\mathrm{RR})+0.00003(\mathrm{PL})$

$$
\mathrm{R}^{2}=0.9923
$$

SP, \% $=80.2923+0.1097\left(\right.$ IRS) $-309.3820\left(\right.$ PS) $+289.1667(\text { PS) })^{2}-0.0276$ (PS)*(IRS)

$$
\mathrm{R}^{2}=0.8681
$$

SP, \% $=353.0642-0.0441(\mathrm{PL})-4.0153(\mathrm{IRS})+0.0114(\mathrm{IRS})^{2}+0.0004(\mathrm{PL}) *(\mathrm{IR}) \mathrm{S}$

$$
\mathrm{R}^{2}=0.9972
$$

The first equation indicated that increasing the punch reciprocated radius (RR) by one unit increasing the multiple index about 1.36 times at constant punch tube length. But, the medium equation pointed out that increasing the punch speed one unit the multiple index increased about 1.15 at fixed the inter row spacing, while the last equation indicated the same trend.

\section{REFERENCES}

Ismail, Z. E and E.H. El-hanify (2009). Construction and testing the seed-punch planter. Farm Machinery and Power. Misr J. Ag. Eng., 26(1): 597-607.

Ismail, Z.E. (2009) Punch planter precision. Poster in Special Issue for The $16^{\text {th }}$. Annual Conf. of the Misr Society of Agric Eng. "Agricultural Engineering and variables of the present epoch" Ag. Eng. Dept., Fac. Of Ag. Cairo Univ. 25 July 2009

Molin, J. P., L. L. Bashford, K. Von Bargen, and L. I. Leviticus . (2002)

Design and evaluation of a punch planter for no-till systems. Transactions of the ASAE 41(2): 307-314.

PAMI (Prairie Agricultural Machinery Institute). 1984a. Evaluation Report 357. Humboldt, Saskatchewan, Canada.

PAMI (Prairie Agricultural Machinery Institute). 1984b. Evaluation Report 358. Humboldt, Saskatchewan, Canada.

Schueller, J. K. 1992. A review and integrating analysis of spatiallyvariable control of crop production. Fertilizer Res. 33: 1-34. 
West D. R., C. R. Graces, D. R. Kincer, and J. F. Bradley. 1998. Response corn hybrids to varying plant population densities. Tennessee Farm \& Home Sci. 150: 10-14 .

$$
\begin{aligned}
& \text { الملخص العربيى } \\
& \text { الزراعة بالدفع ـ المواصفات والتقييم }
\end{aligned}
$$

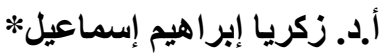

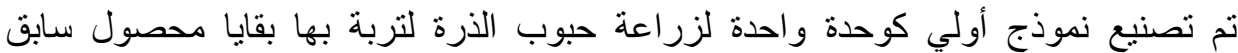

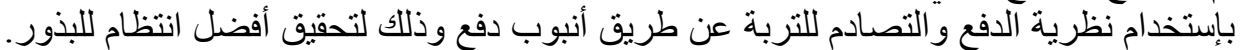

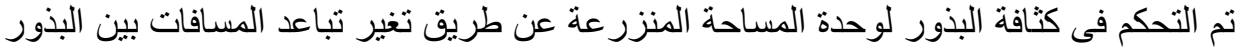

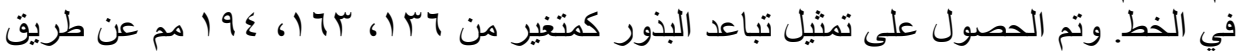

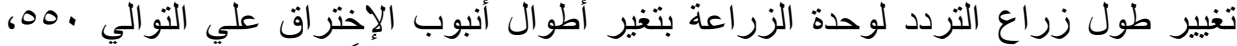

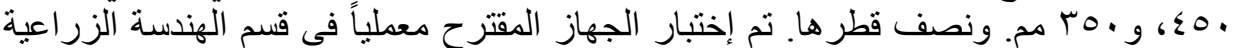

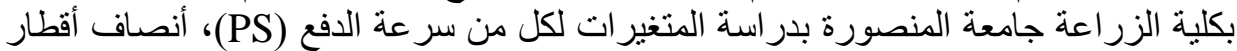

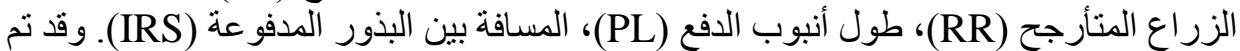

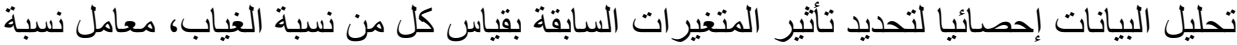

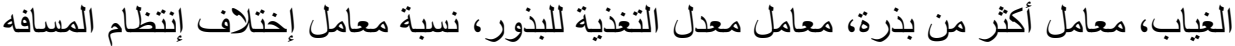

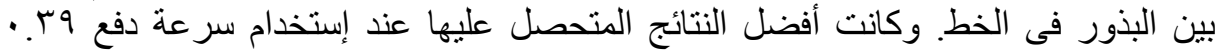

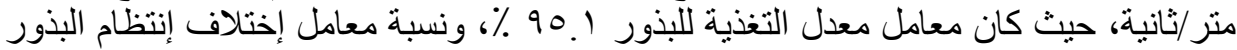

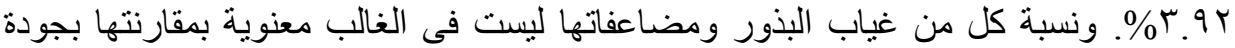
معدل التغذية حيث سجلت 9 ب. • م/ث أقل قيمة لها. 